\title{
WHITE-THREAD BLIGHT: FIVE NEW HOSTS IN THE STATE OF PARÁ, BRAZIL
}

\section{RUTH L. BENCHIMOL, LUIZ S. POLTRONIERI, DINALDO R. TRINDADE \& FERNANDO C. ALBUQUERQUE}

\author{
Embrapa Amazônia Oriental, Cx. Postal 48, 66017-970, Belém, PA, fax: (91) 276-9845, \\ e-mail: rlinda@cpatu.embrapa.br
}

(Accepted for publication on 26/06/2001)

Corresponding author: Ruth L. Benchimol

\section{RESUMO \\ Queima-do-fio: cinco novos hospedeiros no Estado do Pará, Brasil}

Levantamentos na região Bragantina, PA, detectaram o ataque de Ceratobasidium stevensii em Neem (Azadirachta indica), mogno africano (Khaya ivorensis), coqueiro (Cocos nucifera), bananeira (Musa sp., cv. yangambi) e Ixora (Ixora coccinea). A patogenicidade de $C$. stevensii foi comprovada para cada hospedeiro.
Since the first description of Pellicularia koleroga Cooke, at present classified as Ceratobasidium stevensii (Burt) Venkat. (sin: Corticium koleroga (Cooke) v. Höhn., Koleroga noxia Donk, Botryobasidium koleroga Cooke) by Deslandes (Bol. Fitossanitário 1:197, 1944), more than 40 important agricultural and forestry species were reported to be damaged by the white-thread blight, making evident the importance of that pathogen to the Amazon region (Albuquerque, Seminário Técnico, EMBRAPA-IPEAN, 1973; Silva et al., Fitopatol. bras., 8:601, 1983; Lourd \& Alves, Fitopatol. bras., 12:88, 1987; Furtado, Manual de Fitopatol., 1997; Benchimol \& Müller, Embrapa-CPATU, Comunicado Técnico 99, 1999; Gasparotto \& Silva, Fitopatol. bras., 24:469, 1999).

C. stevensii penetrates the plant by natural chaps or twig axils, showing up as whitish mycelial cords (rhizomorphs) that develop upon the host twigs and leaves, causing them to dry. The dead leaves remain hanged on the twigs by the pathogen mycelium as a characteristic sign of the white-thread blight (Figure 1). Morphological and physiological characteristics of the pathogen and disease control were described by Roger, L. (Phytopathologie des Pays Chauds, Lechevalier, 1949).

Surveys on Bragantina region plantings, State of Pará, Brazil, detected damages caused by C. stevensii on Neem (Azadirachta indica A. Juss.), African mahogany (Khaya ivorensis A. Chev.), coconut (Cocos nucifera L.), banana (Musa L. cv. yangambi) and ornamental Ixora (Ixora coccinea L.). Reproduction of white-thread blight symptoms under greenhouse conditions was obtained about one week after mycelial PDA plug inoculation on the abaxial face of the young leaves of these hosts left in a dew chamber for $48 \mathrm{~h}$.

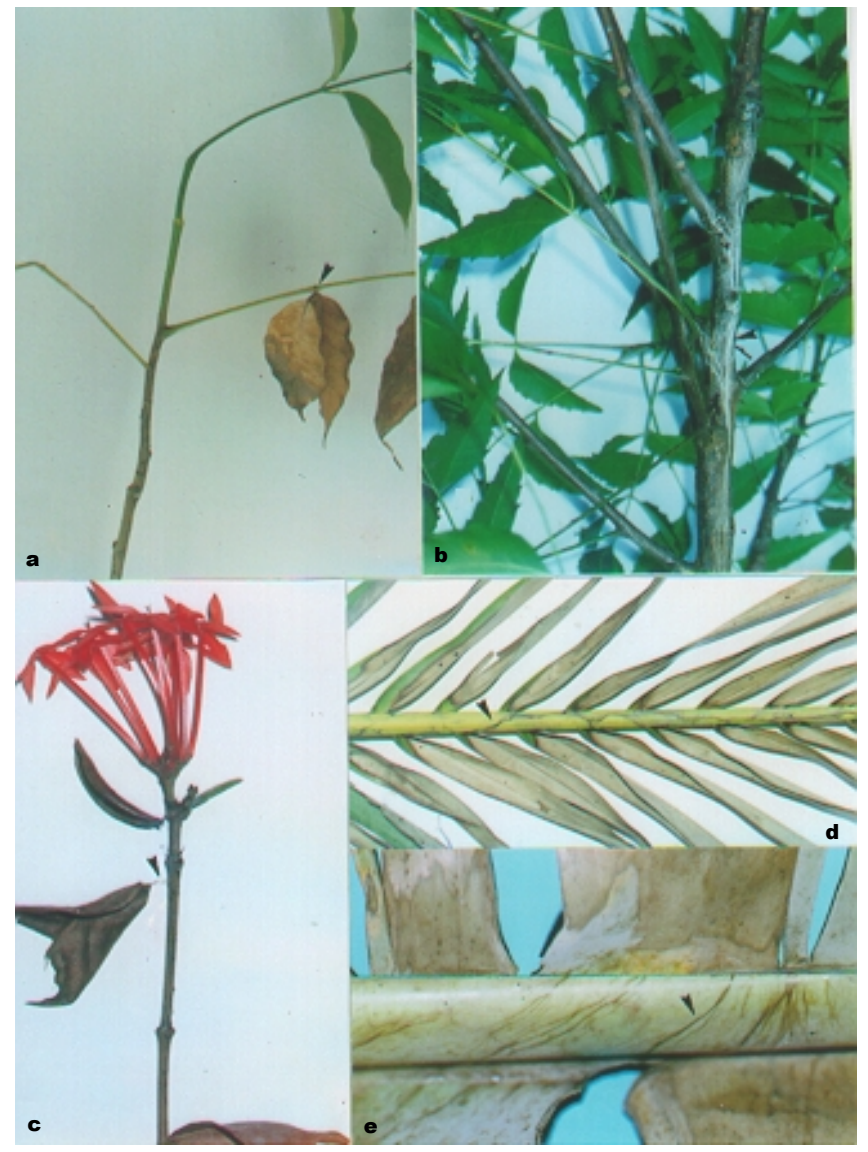

FIG. 1 - Signs of Ceratobasidium stevensii (arrows) on (a) K. ivorensis; (b) A. indica; (c) I. coccinea; (d) $C$. nucifera; (e) Musa sp. 